\title{
Spatial and temporal variability of suspended sediment yield in the Kamchatka Krai, Russian Federation
}

\section{LIUDMILA KUKSINA \& NIKOLAY ALEXEEVSKY}

Department of Hydrology, Faculty of Geography, Moscow State University, Leninskie Gory, GSP-1, Moscow, 119991, Russia ludmilakuksina@gmail.com

\begin{abstract}
Research into the spatial and temporal variability of suspended sediment flux (SSF, $t$ year ${ }^{-1}$ ) has been conducted for rivers in the Kamchatka Krai (in the far east of the Russian Federation). The study of long-term fluctuations in SSF was based on difference-integral curve analysis. Most of the rivers in the region are characterized by two relatively long-term trends in SSF; increases from the late 1970s to the early 1980 s, followed by a subsequent decline. Kamchatka was divided into regions based on similar conditions of specific suspended sediment yield (SSSY, $\mathrm{t} \mathrm{km}^{-2}$ year $^{-1}$ ) followed by a determination of the various factors controlling it. New maps of suspended sediment concentration (SSC, $\mathrm{mg} \mathrm{L}^{-1}$ ) and SSSY for Kamchatka also were constructed and, based on this study, there currently appear to be 18 SSC and 13 SSSY regions, as opposed to 4 and 2 regions, respectively, as had been determined in the 1970s. The influence of volcanoes on SSF can be substantial, and can increase up to 5-fold after eruptions; SSC can reach $6 \cdot 10^{5} \mathrm{mg} \mathrm{L}^{-1}$ in rivers draining the flanks of volcanoes.
\end{abstract}

Key words suspended sediment concentration; volcanic eruptions; rainfall erosive factor; specific sediment yield; suspended sediment concentration; multiple regressions; Kamchatka Krai, Russia

\section{INTRODUCTION}

Rivers in the Kamchatka Krai are characterized by various flow regimes and different sources of suspended sediment (turbidity). There are no significant human impacts on suspended sediment concentration (SSC), except in the mining areas in the northern part of the krai (Koryakia). As a result, long-term spatial and temporal variations in suspended sediment flux (SSF) and SSC are predominantly controlled by natural factors, particularly the presence of numerous active and extinct volcanoes. This is due to the presence of substantial amounts of erodable material on volcanic hillslopes (Kuksina 2013). Information on SSC and specific suspended sediment yield (SSSY) is needed for establishing environmental restrictions because many of the rivers in the region are spawning areas for several salmonid species (king salmon, silver salmon, red salmon, etc.). Salmonid populations can be limited because of SSC and lack of gravel-bed stream segments for spawning (Leshkov 1985; Young \& Woody 2007). As a result, uncontrolled increases in SSC can lead to poor reproductive success for these types of fish (Kerr 1995).

The SSF of rivers is mainly controlled by geological factors such as relief and lithology, as well as by climatic factors such as precipitation, and soil-vegetative cover (Sediment transport 2011; Wischmeier \& Smith 1971). As noted above, volcanic activity also is a specific factor affecting SSF in Kamchatka (Dadson et al. 2004; Davila et al. 2007; Hayes et al. 2002; Kuksina \& Chalov 2012). Hydrologically, Kamchatka is one of the most poorly studied regions in the Russian Federation (Dedkov \& Mozgerin 1984; Milliman \& Syvitski 1992; Sediment yield 1977). As a result, SSF assessments based on the application of traditional approaches using SSC and sediment yield maps lead to substantial underestimates of the impact of factors such as relief, precipitation, rock lithology, soil-vegetative cover, and volcanic eruptions, as well as to calculation errors.

One method of addressing the problem of inadequate hydrological data could be based on dividing the Kamchatka Krai into specific districts that are characterized by similar levels of SSF. In turn, this zonation could form the basis for creating predictive regression equations based on the main factors controlling SSF in each specific zone (Clapcott et al. 2011). The steps required for SSF zonation are:

(a) Analysis of available data on SSF in Kamchatka;

(b) Study of the temporal variability in SSF;

(c) Identification of the relative impacts of the factors affecting SSF;

(d) Geographical demarcation of the Kamchatka Krai into zones with similar SSFs; 
(e) Spatial analysis of SSF variability;

(f) Evaluation of the relative impact of the factors controlling SSF in each zone; and

(g) Creation of multiple regression equations for SSSY assessment in ungauged river basins.

This approach was implemented for both permanent and ephemeral rivers in the Kamchatka Krai, which includes the Kamchatka Peninsula, rivers flowing into Penzhina Bay (from Cape Taigonos in the west, to Rekkininsky Bay in the east), and those flowing into the Bering Sea (from the Anapka River mouth in the southwest to Cape Pyatnisty in the northeast; see Fig. 1). This study is based on sediment discharge monitoring in 56 rivers between 1940 and 2010, and water discharge measured at 63 gauges between 1930 and 2010. It also incorporates additional fieldwork between 2003 and 2012 in selected rivers flowing through the Kliuchevskoy and the Avachinsky volcanic groups, and in the Koryak Mining District, as part of an ongoing GIS project titled "Factors Affecting Specific Sediment Yield in Kamchatka". The significance of the factors affecting SSF in the Kamchatka Krai also are described herein.

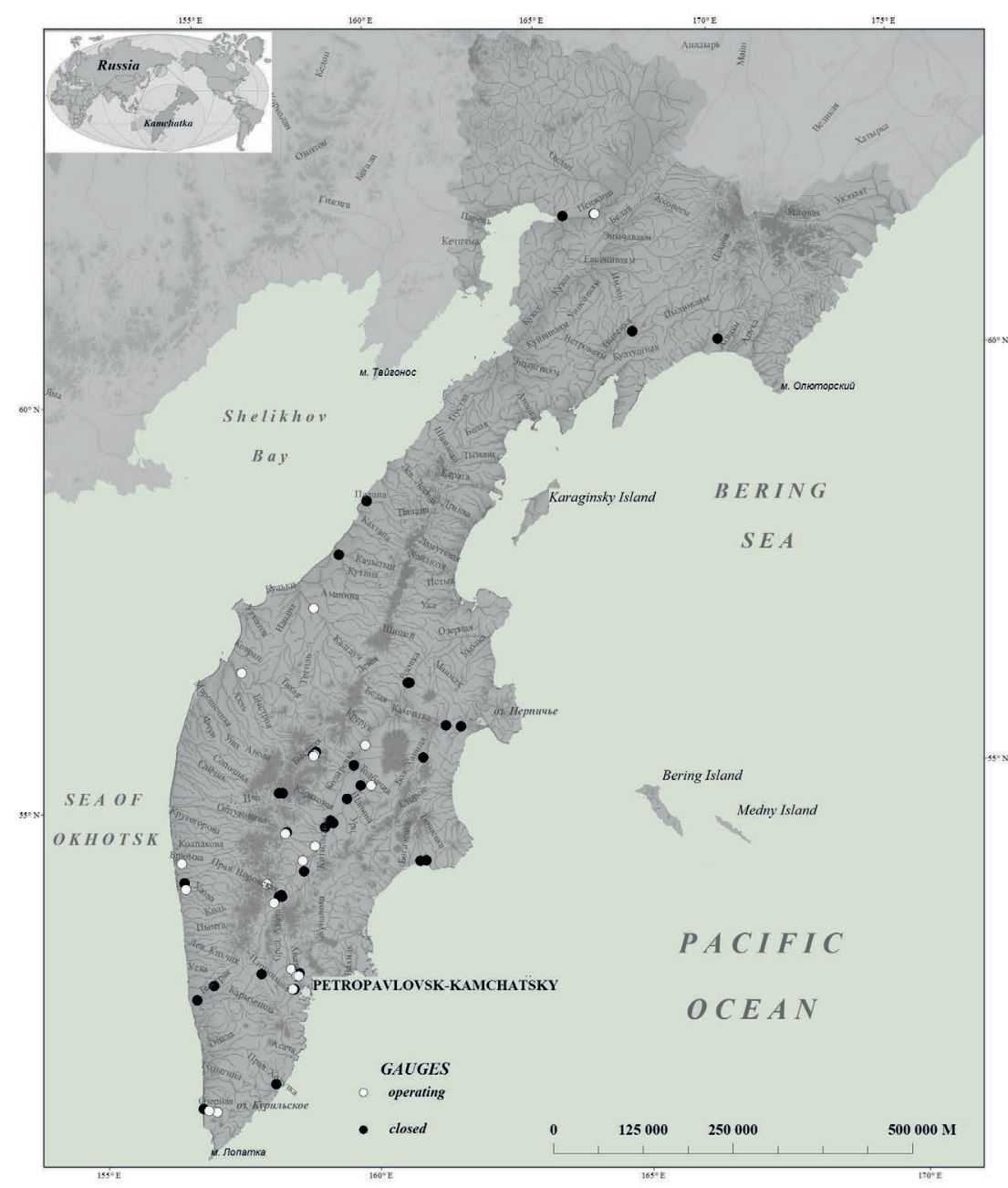

Fig. 1 Gauges with SSF characteristic measurements in the Kamchatka Krai.

\section{METHODS}

Monitoring SSF characteristics in the Kamchatka Krai began in 1940 in the Kamchatka and the Avacha rivers. The majority of sediment gauges are located in the Kamchatka River basin where, between 1940 and 2010, observations were collected at 35 gauges, or on average, at one gauge per $1530 \mathrm{~km}^{2}$. In total, between 1940 and 2010, SSF measurements were collected at 69 gauges; 
however, observations at six sites appear to be non-representative and were excluded from this study (see Fig. 1). Monitoring duration ranged from 6 to 71 years. More than half the gauges $(54 \%)$ were situated in river basins with catchment areas $>500 \mathrm{~km}^{2}$, hence, $46 \%$ were in river basins with areas $<500 \mathrm{~km}^{2}$.

Typically, SSF measurements at most gauges in the Kamchatka Krai do not cover the entire year. As a rule, observations only are made during spring floods, and summer to autumn storm events, when SSC is much higher than during low-flow periods. As a result, mean annual SSFs tend to represent overestimates of at least $50 \%$ or more. To limit these estimation errors, the unmeasured gaps were estimated using rating curves based on the following formula:

$$
C_{m}=f\left(Q_{m}\right)
$$

where $C_{m}$ is mean monthly SSC $\left(\mathrm{mg} \mathrm{L}^{-1}\right)$, and $Q_{m}$ is mean monthly water discharge $\left(\mathrm{m}^{3} \mathrm{~s}^{-1}\right)$. The use of this relationship provided estimates for the missing measurements at 63 gauges in Kamchatka rivers because complete annual discharge measurements were available. As a result, much more accurate annual values of SSF were obtained. The relationship between mean monthly water discharges and mean monthly SSC display strong positive correlations, on the order of about 0.85-0.97 for all gauges. The utility of this method appears to be satisfactory, based on comparisons between estimated and measured values that tend to fall within measurement errors.

The representativeness (Helsel \& Hirsch 2002) of all the series of observations also was evaluated. Even measurement periods as short as 6 to 10 years appear representative. As a result, these data were used for defining zones having similar SSF characteristics. Our assessment of long-term SSF fluctuations was based on difference-integral curve analysis $\left(S_{\mathrm{t}}\right)$ that led to our ability to define whether water runoff and sediment yield were increasing or decreasing in selected Kamchatka rivers.

Available data on SSSY observations appear insufficient for a reliable assessment of this same parameter in ungauged rivers. As a result, a method(s) that allows estimates of sediment yield from unmonitored sites is required. Such estimates could be based on multiple regressions (Helsel \& Hirsch 2002), and require a division of the Kamchatka Krai into zones with similar factors that control SSF. In turn, the estimates from these specific zones can lead to a better understanding of the relative impacts of various environmental factors on SSF. Based on the results of this study, the main factors affecting sediment yield in the Kamchatka Krai appear to be relief, precipitation, underlying surface lithology, and soil-vegetative cover.

The most significant factor for defining various SSF zones in the Kamchatka Krai appears to be relief, which results in substantial erosional areas in mountainous regions, and substantial depositional areas in low-lying, relatively flat regions. The relief ranges from highlands and volcanoes, to vast inter-montane troughs, to foothill plains, to coastal lowlands. Tectonic activity appears to exercise the most control on the Kamchatka Krai relief. Volcanic processes also influence surface formations, and relief is mostly of volcanic origin in Kamchatka. Further, the main relief elements trend NNW along the peninsula's longitudinal axis. The continental part of the Kamchatka Krai is characterized by a complicated distribution of mountain ranges and intermontane troughs.

An analysis of digital elevation maps (DEMs) has led to the identification of 11 orographic zones in the Kamchatka Krai based on average relief and slope angle. Relatively flat areas occupy about $35 \%$ of the Kamchatka Krai, of which the western Kamchatka plain is the largest These regions differ in their relief erosive index $L \cdot S$, where $L$ is the slope-length factor (the ratio of soil loss from the field slope length to that from a $22.13 \mathrm{~m}$ length under identical conditions), and where $S$ is the slope-steepness factor (the ratio of soil loss from the field slope gradient to that from a 9-percent slope under otherwise identical conditions (Wischmeier \& Smith 1971). The $L: S$ factor attains maximum values in mountainous regions (especially in zones of active volcanism) and minimum values in areas of low-lying plains.

Climatic factors (notably the distribution of precipitation) also provide a basis for dividing the Kamchatka Krai into distinct zones. The rainfall erosive factor $R$ has particular importance for controlling SSF. $R$ represents the number of rainfall erosion index units, and characterizes the 
erosive potential of precipitation (Litvin 2002; Wischmeier \& Smith 1971). For the Kamchatka Krai, the distribution of the rainfall factor was obtained by combining data from $R$-distribution maps (Larionov 1993) with more recent precipitation data (since 2010). Maximum values of the index (8) are found in the eastern part of the peninsula, whereas minimum values are found in the continental part of the peninsula (Fig. 1).

By combining relief and precipitation characteristics, the Kamchatka Krai can be divided into 26 regions (see Fig. 2(a)) that display similar SSFs. Division of the territory into smaller regions (based on more localized SSF measurements affected by soil-vegetative cover and rock lithology) currently is unjustified due to a lack of sufficient observational data.

The 26 identified regions are characterized by a sparse network of sediment gauges that also are irregularly distributed. More than half the gauges (from a total of 63) are situated in the Kamchatka River Basin. The 26 Kamchatka regions were reduced to a total of 11 based on available SSF values (see Fig. 2(b)). In each region, SSF depends on a unique combination of factors such as relief, precipitation, soil-vegetative cover, etc.
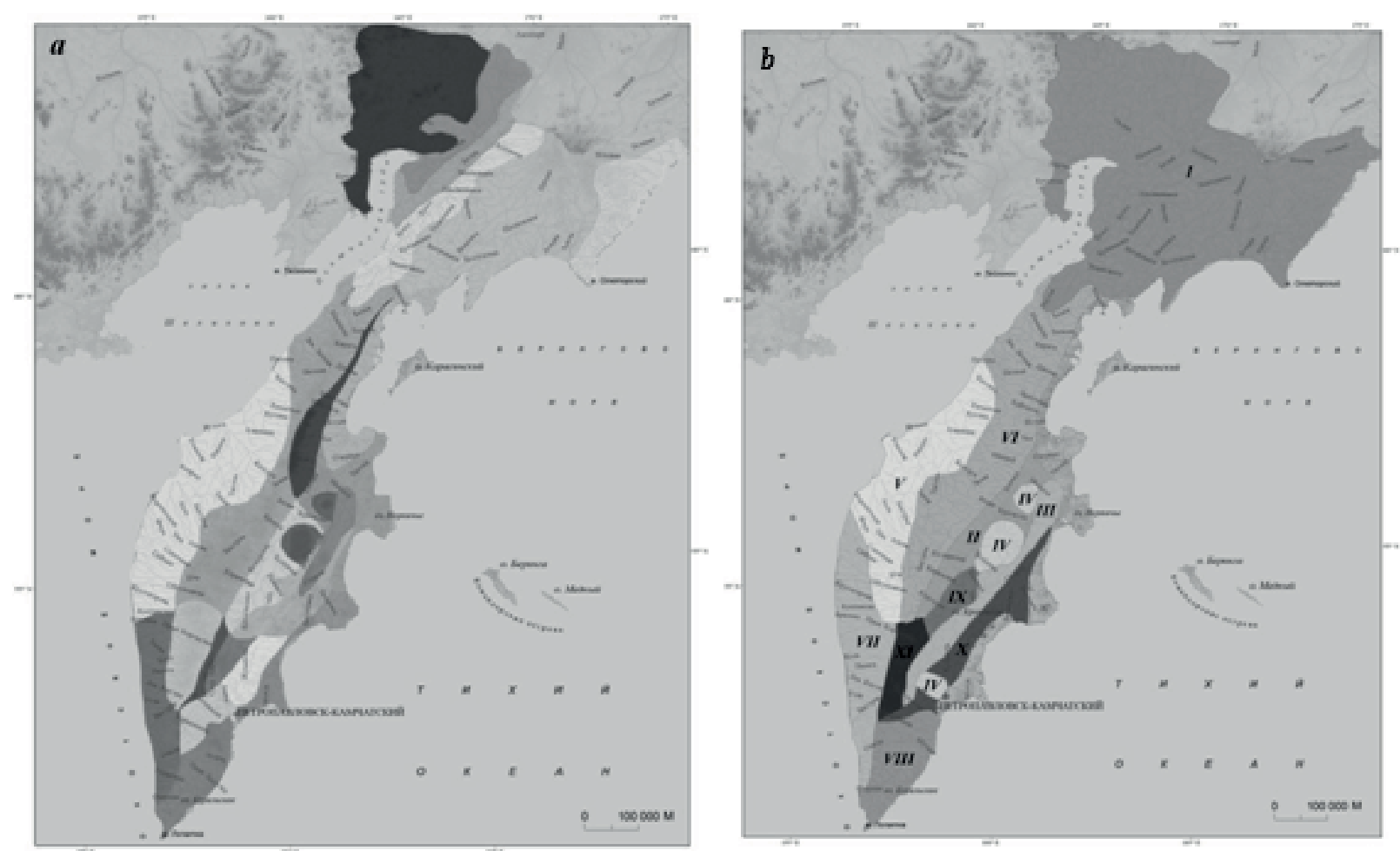

Fig. 2 Areas displaying similar SSFs (a) and their integration into larger districts based on available data (b).

The available data permit construction of multiple regression equations (2) (Nisbet et al. 2009) that can be used to estimate SSSY based on a variety of factors:

$$
y_{i}=b_{1} x_{1 i}+b_{2} x_{2 i}+\cdots+b_{p} x_{p i}+b_{0}
$$

where: $y_{i}$ represents specific sediment yield $\left(M_{R}, \mathrm{t} \mathrm{km}^{-2}\right.$ year-1), $x_{1 i}, x_{2 i}, \ldots x_{p i}$ are independent variables such as specific water discharge $M_{Q}\left(\mathrm{~L} \mathrm{~km}^{3} \mathrm{~s}^{-1}\right)$; catchment basin area $F\left(\mathrm{~km}^{2}\right)$; mean slope of catchment $I_{H}(\%)$; average river slope $\bar{I}(\%)$; drainage density $\alpha\left(\mathrm{km} \mathrm{km}^{-2}\right)$; percentage of forest land $f(\%)$; rivers draining flanks of active volcanoes in a catchment $\left(\mathrm{F}_{\mathrm{vol}} \mathrm{F}^{-1}\right)$; coefficient of friable volcanic rocks present in a catchment $\left.\left(\mathrm{F}_{\text {friable }} \mathrm{F}^{-1}\right)\right)$; and $b_{0}, b_{1}, \ldots, b_{p}$ are unknown model parameters, estimated from normal equation systems (Helsel \& Hirsch 2002; Lisicina 1974; Tkacheva 1974). 


\section{RESULTS AND DISCUSSION}

Most Kamchatka Krai rivers are characterized by two relatively long trends in water runoff and SSF fluctuations. Runoff and SSF increased from the late 1970s to the early 1980s, and then declined thereafter. This pattern in Kamchatka rivers appears to be independent of basin area. Rivers in the northern (continental) part of the region appear to be characterized by two relatively long SSF trends. There was an increase in runoff between 1957 and 1974, with a subsequent decline between 1975 and 2010 (Fig. 3 (i)). Rivers in the western part of the peninsula display no long-term trends; water runoff and SSF increased from 1976 to 1981, appeared close to normal between 1982 and 1996, and declined after 1997 (Fig. 3 (ii)). In the eastern part of the peninsula, water runoff and SSF increased synchronously between 1941 and 1977, and then subsequently declined (Fig. 3 (iii)). In the central part of the peninsula (the Kamchatka River Basin) two phases of water runoff and SSF fluctuations occurred; reduced runoff was observed from the mid 1950s to the 1960 s, followed by a period of increased runoff (Fig. 3 (iv)).

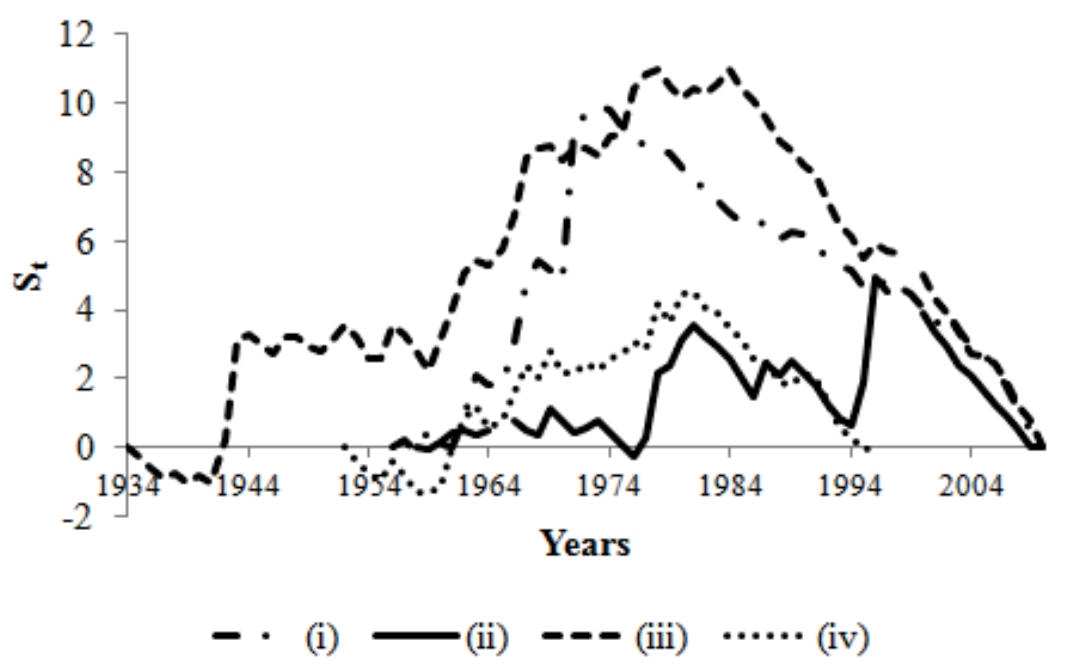

Fig. 3 SSF fluctuations in the Northern [(i), the Pengina River], Western [(ii), the Hayruzovo River], Eastern [(iii), the Avacha River], and Central [(iv), the Kirganik River] parts of the Kamchatka Krai.

The long-term trends in river runoff and SSF described previously display substantial interruptions in response to volcanic eruptions. The maximum increase in SSSY was measured in the Kamchatka and the Tolbachick Rivers after the major eruptions of the Bezymyanny (1956), Shiveluch (1964), and Plosky Tolbachick (1974-1975) volcanoes (Fig. 4).

Mean annual SSC and SSSY maps for the Kamchatka Krai were constructed using SSF data from 63 gauges in rivers with observational durations ranging from 6 to 71 years. SSC maps (Fig. 5(a)) display as many as 18 different zones (instead of the 4 zones mapped previously; Sediment yield, 1977); average annual SSC changes range from 10 to $>1000 \mathrm{mg} / \mathrm{L}$. There also appears to be $13 \mathrm{SSSY}$ zones that display variations ranging from 5-10 to $>500 \mathrm{t} \mathrm{km}^{-2}$ year $^{-1}$ (Fig. $5(\mathrm{~b}))$.

SSCs in rivers in the western part of the Kamchatka Krai are considerably less than in the rivers of the Eastern region. There are huge volcanic massifs in the eastern part of Kamchatka, and their eruptions are a constant source of inorganic suspended sediment to these rivers. The most intense ash falls occur here (Ponomareva et al. 2007), and they have significant impact on both the soil and vegetative cover, which in turn, control the intensity of hillslope erosion.

Regions with the lowest SSCs $\left(\leq 10 \mathrm{mg} \mathrm{L}^{-1}\right)$ are located in the southwest part of the peninsula, in the central part of the Central Range, and in the isthmus between the peninsula and the continental part of the Kamchatka Krai (Fig. 5(a)). They are characterized by containing areas with highly resistant rock types that appear impervious to high levels of precipitation. Erosion also is limited by the presence of substantial vegetative cover. 


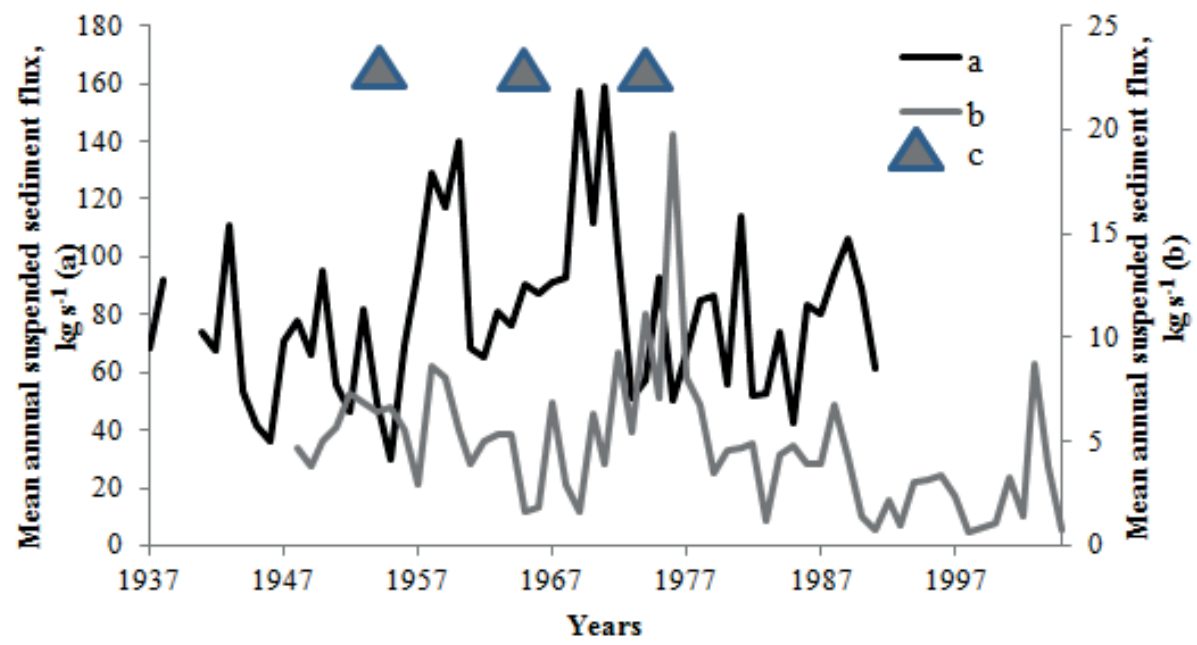

Fig. 4 Relationship between mean annual suspended sediment flux increase and major volcanic eruptions: a - Kamchatka River (Bolshie Sheki hole), b - Tolbachick River (Tolbachick settlement), $\mathrm{c}$ - eruptions of Bezymyanny, Shiveluch, and Plosky Tolbachick volcanoes.
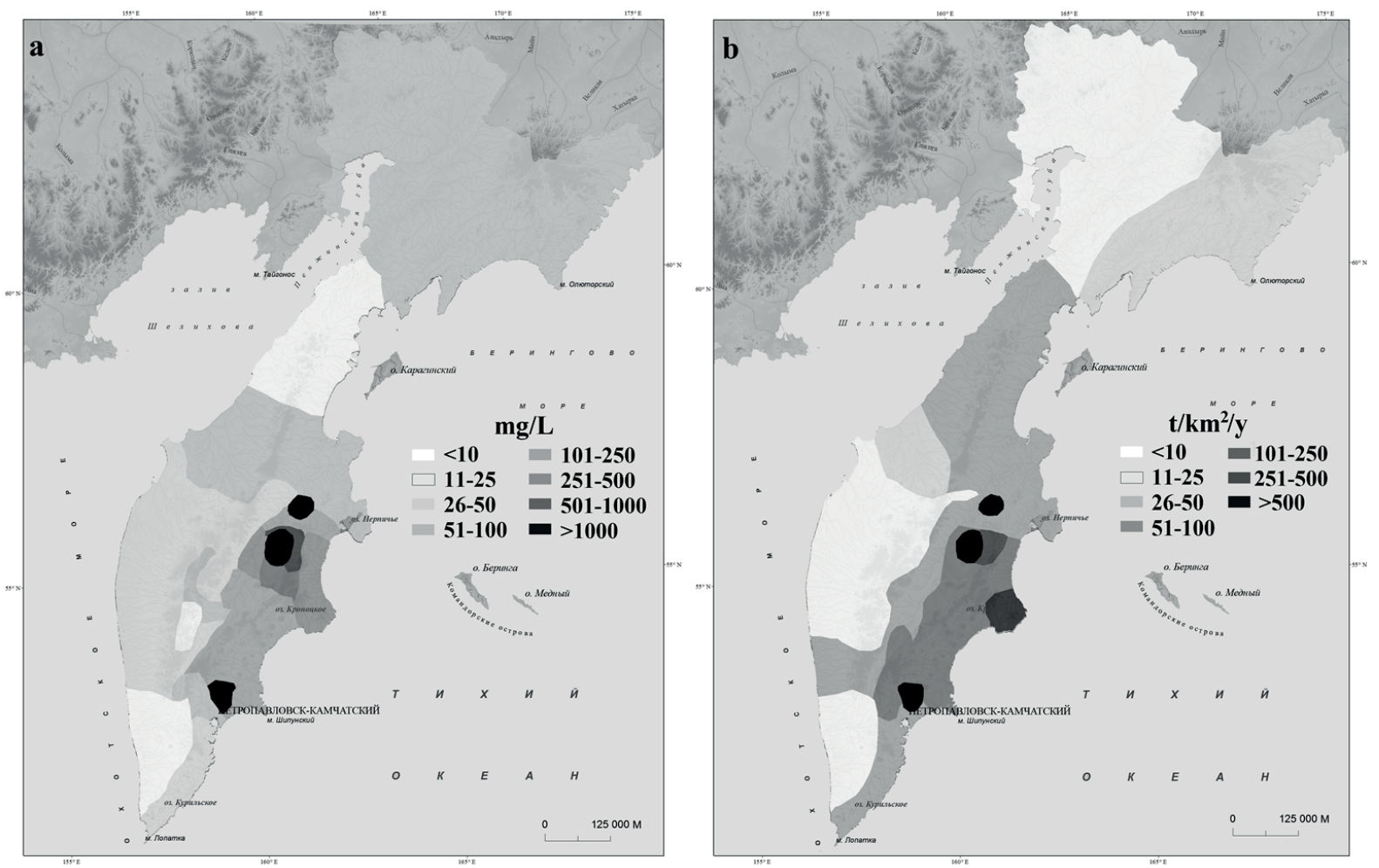

Fig. 5 Suspended sediment concentration (a) and specific sediment yield (b) in the Kamchatka Krai.

SSCs of 11-50 mg L $\mathrm{m}^{-1}$ characterize the western and southeastern parts of the peninsula, as well as continental Kamchatka (Fig. 5(a)). Soils in these areas display relatively high levels of erodibility, provided the bedrock is resistant to erosion.

Considerable increases in SSC have been observed in the eastern regions of the peninsula where active volcanoes are situated. SSCs decrease with increasing distance from volcanic zones. The zone of maximum SSC coincides with the location of the Kliuchevskoy volcanic group (Fig. 5(a)). Close to volcanoes, SSCs can exceed values of $10^{5}-10^{6} \mathrm{mg} \mathrm{L}^{-1}$, and for some rivers, it reaches values $>2 \cdot 10^{5} \mathrm{mg} \mathrm{L}^{-1}$ (the maximum measured value is $6 \cdot 10^{5} \mathrm{mg} \mathrm{L}^{-1}$ ). Such elevated SSCs are associated with easily erodible bedrock, maximum values of soil erosion, the absence of 
vegetative cover, and high levels of precipitation. The SSF associated with the slopes and flanks of active volcanoes actually depends on the number and magnitude of volcanic eruptions. The maximum SSFs in the Kamchatka River were observed after major eruptions.

The distribution of SSSY in the Kamchatka Krai coincides with the distribution of SSC. Minimum values characterize continental Kamchatka and its western regions, whereas maximum values are observed in volcanic areas (Fig. 5(b)). However, SSSY is controlled by a complex group of factors that affect the spatial variations in SSC and fluvial sediment transport (SSF). An understanding of these factors may lead to reasonable estimates of SSSY in ungauged river basins (Sediment Yield, 1977). Such studies have been implemented in sections of the European part of the Russian Federation, Siberia, in parts of central Asia (Lisicina 1974; Tkacheva 1974), and in the Ukraine (Goreckaya 1974).

Based on this study, the Kamchatka Krai was divided into 11 regions (Fig. 2(b)), each characterized by similar conditions of SSF in conjunction with the various factors affecting SSSY, based on multiple regression equations developed from available observational data (Table 1). Some of these equations (e.g. Regions I, II, III, IV, X) appear to provide estimates with relatively small errors compared to observed values and could be used for SSSY assessments in ungauged river basins.

Table 1 Multiple regression equations (2) for erosive regions in the Kamchatka Krai. See equation (2) for description of variables.

\begin{tabular}{|c|c|c|c|}
\hline No. & Region & Regression & $\begin{array}{l}\text { Relative } \\
\text { error, \% }\end{array}$ \\
\hline I & $\begin{array}{l}\text { Northern, including } \\
\text { river basins in } \\
\text { continental part of } \\
\text { Kamchatka }\end{array}$ & $M_{R}=b_{11} M_{Q}-b_{01}$ & $4.1-15.9$ \\
\hline II & $\begin{array}{l}\text { The Kamchatka River } \\
\text { basin (downstream) }\end{array}$ & $M_{R}=b_{12} \alpha-b_{02}$ & $0-1.6$ \\
\hline III & $\begin{array}{l}\text { Downstream tributaries } \\
\text { of the Kamchatka Rivers }\end{array}$ & $M_{R}=b_{13} M_{Q}+b_{23} f-b_{03}$ & $0.5-8.5$ \\
\hline IV & $\begin{array}{l}\text { River basins in the zone } \\
\text { of active volcanism }\end{array}$ & $M_{R}=b_{14} l g F+b_{24} \bar{I}+b_{34} f+b_{44} \frac{F_{v o l}}{F}-b_{54} \frac{F_{\text {friable }}}{F}-b_{04}$ & $0.3-20.6$ \\
\hline V & $\begin{array}{l}\text { River basins in the } \\
\text { northwestern part of the } \\
\text { peninsula }\end{array}$ & $M_{R}=b_{15} I_{H}-b_{05}$ & $5.0-69.0$ \\
\hline VI & $\begin{array}{l}\text { Left-bank tributaries of } \\
\text { the Kamchatka River in } \\
\text { middle course }\end{array}$ & $M_{R}=b_{16} M_{Q}-b_{06}$ & $20.0-700$ \\
\hline VII & $\begin{array}{l}\text { River basins in the } \\
\text { southwestern part of the } \\
\text { peninsula }\end{array}$ & $M_{R}=b_{17} \lg F+b_{27} I_{H}-b_{07}$ & $0.5-143$ \\
\hline VIII & $\begin{array}{l}\text { River basins in the } \\
\text { southeastern part of the } \\
\text { peninsula }\end{array}$ & $M_{R}=b_{18} \bar{I}+b_{28} I_{H}-b_{08}$ & $1.3-45.5$ \\
\hline IX & $\begin{array}{l}\text { Right-bank tributaries of } \\
\text { the Kamchatka River in } \\
\text { middle course }\end{array}$ & $M_{R}=b_{19} \alpha+b_{29} \bar{I}-b_{09}$ & $8.0-131$ \\
\hline $\mathrm{X}$ & $\begin{array}{l}\text { River basins in the } \\
\text { eastern part of the } \\
\text { peninsula }\end{array}$ & $M_{R}=b_{110} f-b_{210} \bar{I}-b_{310} M_{Q}+b_{010}$ & $0.2-7.5$ \\
\hline XI & $\begin{array}{l}\text { The Kamchatka River } \\
\text { basin (upstream) }\end{array}$ & $M_{R}=b_{111} M_{Q}+b_{211} f+b_{011}$ & $9.6-276$ \\
\hline
\end{tabular}

\section{CONCLUSIONS}

The Kamchatka Krai can be divided into specific regions based on the SSF in its rivers. SSF appears to be affected most by factors such as relief, the amount and distribution of precipitation, and soil-vegetative cover, as well as by the occurrence of volcanic eruptions. Most of the rivers in 
the territory are characterized by two relatively long trends in SSF and water runoff fluctuations: (1) increases from the late 1970s through the early 1980s, followed by (2) a measurable decline in both thereafter. This rather regular pattern is interrupted in rivers directly impacted by volcanic eruptions.

Maximum SSC and SSSY are observed in rivers along the eastern coast of the peninsula. This appears to be due to the presence of a substantial number of active volcanoes that serve as constant sources of inorganic sediment. Minimum SSC values characterize western parts of the Kamchatka Peninsula due to the presence of erosion-resistant bedrock, low soil erodibility, and the presence of erosion-resistant vegetative cover.

The Kamchatka Krai is one of the least studied regions in the Russian Federation. The lack of a relatively good monitoring network for the determination of SSF requires the development of new approaches for estimating this parameter in ungauged river basins. One approach to that problem is based on region-specific multiple regression equations. These relationships were developed for 11 zones in the Kamchatka Krai that display similar SSF values. The most significant factors affecting SSF appear to be water discharge, catchment area, mean catchment altitude, the mean slope of the catchment, the average slope of the river, drainage density, percentage of forest land, the number of active volcanoes present, and the coefficient of friable volcanic rocks in the catchment.

Acknowledgements The study was supported by the Russian Foundation for Basic Research (project no. 12-05-00069-a) and the Russian Science Foundation (project no. 14-17-00155).

\section{REFERENCES}

Apollov, B.A., Kalinin, G.P. and Komarov, V.D. (1974) Course of Hydrological Forecasts. Leningrad: Gidrometeoizdat, 419 pp.

Clapcott, J.E., et al. (2011) Sediment Assessment Methods: Protocols and guidelines for assessing the effects of deposited fine sediment on in-stream values. Cawthron Institute, Nelson, New Zealand. $108 \mathrm{pp}$.

Dadson, S.J., et al. (2004) Earthquake-triggered increase in sediment delivery from an active mountain belt. Geology 32, 733-736.

Davila, N., et al. (2007) Recent lahars at Volcán de Colima (Mexico): Drainage variation and spectral classification. Journal of Volcanology and Geothermal Research 165, 127-141.

Dedkov, A.P. \& Mozzherin, V.I. (1984) Erosion and Sediment Yield on the Earth. Kazan. 264 pp. In Russian with an English summary.

Hayes, S.K., Montgomery, D.R. and Newhall, C.G. (2002) Fluvial sediment transport and deposition following the 1991 eruption of Mount Pinatubo. Geomorphology 45, 211-224.

Helsel, D.R. and Hirsch, R.M. (2002) Statistical methods in water resources. Techniques of Water-Resources Investigations of the United States Geological Survey, Book 4, Hydrologic Analysis and Interpretation, 524 pp.

Kerr, S.J. (1995) Silt, turbidity and suspended sediments in the aquatic environment: an annotated bibliography and literature review. Ontario Ministry of Natural Resources, Southern Region Science \& Technology Transfer Unit Technical Report TR-008. $277 \mathrm{pp}$.

Kuksina, L.V. (2013) Suspended sediment flux in rivers in the Kamchatka Krai. Abstract of a thesis. 29 pp.

Kuksina, L.V., Chalov, S.R. (2012) The suspended sediment discharge of the rivers running along territories of contemporary volcanism in Kamchatka. Geography and Natural Resources 33(1), 67-73.

Larionov, G. A. (1993) Soil Erosion and Deflation: The main regularities and quantitative evaluation. Moscow, MSU. 200 pp. In Russian.

Leshkov, V. G. (1985) Exploration of Open-pit Mines. Moscow, Nauka, 568 pp. In Russian.

Lisicina, K.N. (1974) Suspended sediment yield of the Siberian rivers. Regime, theory, estimation and measurement methods of sediments and waste waters 210, 48-72. In Russian.

Litvin, L.F. ( 2002) Geography of Soil Erosion in Agricultural Regions of Russia. Moscow. 255 pp. In Russian.

Manning, A.J. (ed.) (2011) Sediment Transport in Aquatic Environments. InTech. 344 pp.

Milliman, J.D. \& Syvitski, J.P.M. (1992) Geomorphic/tectonic control of sediment discharge to the ocean: the importance of small mountainous rivers. Journal of Geology 100, 525-544.

Nisbet, R., Elder, J. and Miner, G. (2009) Handbook of Statistical Analysis and Data Mining Applications. Academic Press, 860 pp.

Ponomareva, V.V., et al. (2007) Late Pleistocene- Holocene volcanism on the Kamchatka Peninsula, Northwest Pacific region. In: Eichelberger, J et al. (eds) Volcanism and Subduction: The Kamchatka Region. American Geophysical Union Geophysical Monograph Series 172, 165-198.

Sediment Yield (Karaushev, A.V. ed.) (1977) Sediment Yield: Its Study and Geographic Distribution. St. Petersburg. 240 p. In Russian.

Tkacheva, L.G. (1974) Suspended sediment yield of the Central Asia rivers. Regime, theory, estimation and measurement methods of sediments and waste waters 210, 73-81. In Russian.

Wischmeier, W.H. \& Smith, D.D. (1978) Predicting Rainfall Erosion Losses:. A Guide to Conservation Planning. USDA-Agric. Handbook no. 537, Washington, DC. 67 pp. In English

Young, D.B. \& Woody C.A. (2007) Spawning distribution of sockeye salmon in a glacially influenced watershed. The importance of glacial habitats. Transactions of the American Fisheries Society 136, 452-459. 